\title{
Bejárók és eljárók: A szuburbanizáció és az általános iskolások ingázásának összefüggései Budapest funkcionális várostérségében
}

\section{Commuting in and out: The relationship between suburbanisation and primary school commuting in the Budapest functional urban area}

\author{
KESERÚ IMRE
}

KULCSSZAVAK: ingázás, agglomeráció, szuburbanizáció, városrégió, közlekedés, általános iskolások, iskolába járás, budapesti funkcionális várostérség

\begin{abstract}
ABSZTRAKT: A napi ingázásban részł vevők jelentős részét alkotják azok a tanulók, akik nem a helyi iskola hiánya miatt, hanem a szülők választása alapján járnak másik településre általános iskolába. Kiváltképp szembetúnő a jelenség Budapest funkcionális várostérségében, ahol különösen a szuburbanizálódó településekről intenziv az ingázás mind Budapestre, mind az agglomeráció más településeire. Tanulmányomban a szuburbanizáció mértéke és az általános iskolások ingázásának intenzitása, valamint iránya közötti összefüggéseket, illetve az iskolások ingázásának következményeit vizsgálom a szuburbanizációs indexre, településsoros ingázási adatokra, valamint egy 2007-es Budapest környéki háztartásfelvétel elemzésére támaszkodva. Eredményeim azł mutatják, hogy a szuburbanizálódó területeken az általános iskolások ingázása intenzivebb: mérsékelten erős korrelációł találtam a szuburbanizációs index és a tanulói elingázás között. Vizsgálataim alapján elmondható, hogy a család magasabb jövedelme, a szülök magasabb iskolai végzettsége és a család birtokában lévő 2 vagy több személygépkocsi esetén nagyobb a valószínúsége annak, hogy az általános iskolás gyermekek másik településre járjanak iskolába. Mivel értelmezésem szerint a szuburbanizálódó településekre is magasabb iskolai végzettség, jövedelem és személygépkocsi-ellátottság jellemző, valószínú, hogy a települések szuburbanizálódása az általános iskolások ingázásának növekedését vonja maga után. Ennek számos negatív környezeti, pénzügyi, egészségügyi és közlekedési következményét ismertetem (a közutak zsúfoltságának növekedése, a kedvezményes diákbérletek állami kompenzációja, a közlekedésbiztonság romlása, a gyermekek mozgásszegény életmódja).
\end{abstract}

KEYWORDS: commuting, agglomeration, suburbanisation, urban region, transport, primary school pupils, commuting to school, Budapest Functional Urban Area

ABSTRACT: A considerable proportion of daily commuters are primary-school pupils who attend school in settlements different from their residence, not because of the

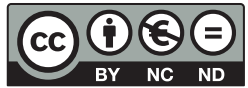


unavailability of schools but as a result of their parents' choice. This phenomenon is quite apparent in Central-Eastern European urban areas including the functional urban area of Budapest, where $21 \%$ of all primary school pupils commute daily to other settlements. Schoolchildren's commuting to Budapest and other settlements in the agglomeration is especially intensive from suburbs. There has been, however, no research carried out on the connection between suburbanisation and commuting to primary schools.

This study examines the relationship between the intensity and direction of school-related commuting as well as the consequences of daily travel to school. The study is based on municipality-level data on school-related commuting and the analysis of a household survey carried out around Budapest in 2007 based on a sample of 600 primary-school-aged children and their 3053 trips. Suburbanisation is measured with a suburbanisation index combining demographic, social and economic data of the municipalities within the functional urban area.

Our results confirm that school-related commuting is more intensive in suburbia: A moderately strong correlation has been found between the suburbanisation index and the number of pupils out-commuting. Out-commuting is particularly intensive from settlements in close proximity to Budapest. In-commuting is highest in Budapest, which has the largest choice of schools in the region attracting many pupils from outside the city. Cross-commuting is also intensive to the satellite towns of the agglomeration.

Considering the proportion of pupils out-commuting from the municipalities, it is two and a half times higher in the agglomeration of Budapest than in municipalities further from the capital. The difference between the proportions of inbound commuters is, however, only 5\%. The proportion of out-commuters is particularly high in the western and north-western sectors of the agglomeration, which are the most suburbanised areas.

A connection between the intensity of suburbanisation and commuting is suggested on the analysis of socio-economic household data. Higher household income, higher qualifications of the parents and two or more cars in the household indicate higher probability of children commuting to a primary school in another settlement. Hence, it is likely that a higher degree of suburbanisation causes more intensive commuting to schools in the functional urban area. This has some transport, economic, health and social consequences: commuting by car contributes to traffic congestion; travelling by public transport incurs compensation from the state budget to finance reduced-price bus and train passes; and using transport to go to school instead of walking may affect children's health by reducing the opportunities for physical activity.

\section{Bevezetés}

A napi ingázás a lakosság széles rétegeit érintő vándorlási folyamat. Az ingázók két fó indoka a munkába járás és az iskolalátogatás. Az ingázás és a szuburbanizáció között szoros összefüggés van, hiszen a folyamat eredményeként a lakóhely és a lakosság napi tevékenységeinek helyszínei (munkahely, iskola) térben eltávolodnak egymástól, legalábbis amíg nem indul meg a szuburbia urbanizálódása. Bár a munkába járás célú ingázás mértékétől jócskán elmarad, az iskolások ingázása is jelentős, hiszen Budapest funkcionális várostérségében 2007-ben 42272 
általános iskolás ingázott másik településre, a térségben élö összes általános iskolás korú 21\%-a. Ugyanezen a területen 2006 és 2010 között 12\%-kal nőtt a településekre bejáró általános iskolások száma, miközben ugyanitt a tanulók összlétszáma 3\%-kal csökkent.

Hasonló folyamat zajlik más kelet-közép-európai országokban is. 2002 és 2008 között például 102\%-kal nőtt a Poznanba ingázó általános iskolások száma. Eközben a Poznannal közvetlenül határos településeken csökkent a helyben iskolába járók száma. Ezek a települések a város szuburbanizálódó gyűrüjében helyezkednek el (Bajerski 2010).

A hazai szuburbanizációs szakirodalom foglalkozott ugyan a szuburbanizáció és a közlekedés, illetve az ingázás összefüggéseivel (Timár 1994, Timár, Baukó 1999, Kovács 1999, Hardi 2002, Kiss 1999), de kifejezetten a diákok ingázását nem vizsgálta. Oktatáskutatók munkáiban ugyan felbukkan az ingázás kérdése (Balázs 2005, Kertesi, Kézdi 2005a, 2005b, Econmet Kft. 2008), de ezek a vizsgálatok elsősorban oktatáspolitikai szemléletűek, a területi elemzések legkisebb szintje megyei, és nem keresik a kapcsolatot a szuburbanizációval. A diákok közlekedésével kapcsolatos kutatások is csak érintőlegesen, az adatgyüjtések egyik hozadékaként foglalkoznak azzal, hogy honnan és milyen módon járnak a gyermekek az iskolába (UNIVERSITAS-Arrabona Kft. 2010, Nemzeti Közlekedési Hatóság 2009). Ez utóbbi kutatások célja elsősorban a közlekedésbiztonsági következmények feltárása volt. A diákok ingázása és a szuburbanizáció közötti kapcsolat kevéssé vizsgált terület, amelynek feltárása elősegítheti a hazai szuburbanizációs folyamatok és következményeik jobb megértését.

Kutatásom szempontjából lényeges és nem megkerülhető a szuburbanizáció fogalmának értelmezése. Nem tekintem feladatomnak egy szuburbanizáció-definíció létrehozását vagy a meglévők értékelését; kutatásom céljához igazodva azonban szükséges a meglévő definíciók közüli választás.

Véleményem szerint a szuburbanizáció intenzitása és az ingázási jellemzők objektív módon leginkább akkor vethetők össze, ha a szuburbanizációt mérni tudjuk. Éppen ezért olyan definíciót választottam, ami magában foglalja a szuburbán települések lehatárolását. Erre azok a meghatározások alkalmasak, amelyek a szuburbanizációt mint az elővárosokat létrehozó folyamatot értelmezik. A szuburbia lehatárolására többféle megközelítést alkalmaznak (lásd Timár 1999). A statisztikai szemléletű definíciók konkrét demográfiai, társadalmi és gazdasági mutatókhoz vagy azok kombinációjához kötik a szuburbanizációt (Timár 1999). Még ha nem is statisztikai definíciót alkottak, a hazai szakirodalomban többen is foglalkoztak a szuburbanizálódó települések lehatárolásával (Kovács 1999, Izsák 1999, Bajmócy 2003). A szuburbanizáció mérésére az adatok hozzáférhetősége és a mutató komplexitása miatt Bajmócy szuburbanizációs indexét tartottam a legalkalmasabbnak² Ennek alapján a szuburbanizálódó településeket összességükben az átlagosnál magasabb szuburbanizációs index jellemzi, amit a pozitív vándorlási különbözet, a lakónépesség és a lakásállomány átlagosnál nagyobb növekedése, valamint átlagnál magasabb személygépkocsi-ellátottság, jövedelem és iskolai végzettség okozhat. 
Korábbi országos vizsgálatok összefüggést találtak az ingázás jellemzői és a diákok családjának jövedelme, a szülők iskolai végzettsége, valamint a család tulajdonában lévő személygépkocsik száma között (Kertesi, Kézdi 2005b, Econmet Kft. 2008). Feltételezem, hogy ezek az összefüggések Budapest funkcionális várostérségében fokozottan érvényesek, hiszen a Budapest környékén végzett korábbi vizsgálatok kimutatták a fővárosból kiköltözők országos és budapesti átlagnál magasabb iskolai végzettségét és jövedelmét (Dövényi, Kovács 1999), illetve a fejlett városkörnyéken a társadalmi és gazdasági státus növekedését (Szirmai 2011).

Mivel ez a tanulmány egy nagyobb, a funkcionális várostérségre kiterjedő kutatás része, jelen vizsgálat területe is Budapest funkcionális várostérsége (FVT), amelyet a 2001-es népszámlálás ingázási adatai alapján határoltam le. A funkcionális várostérség azokat a településeket foglalja magában, amelyekről a helyben lakó foglalkoztatottak legalább 15\%-a Budapestre ingázik munkavállalás céljából (Antikainen 2005). Ez a terület nagyobb, mint a budapesti agglomeráció adminisztratív területe, és nyugati irányban Pest megye területén túlnyúlik Fejér és Komárom megyébe; míg Pest megye Budapesttől távolabbi délkeleti területei kimaradnak belőle. A térségben 170 település található, mintegy 2,8 millió lakossal (1. ábra).

\section{1. ábra: Budapest funkcionális várostérségének kiterjedése és a háztartásfelvételek helyszínei \\ Map of the functional urban area of Budapest and the locations of the household survey}

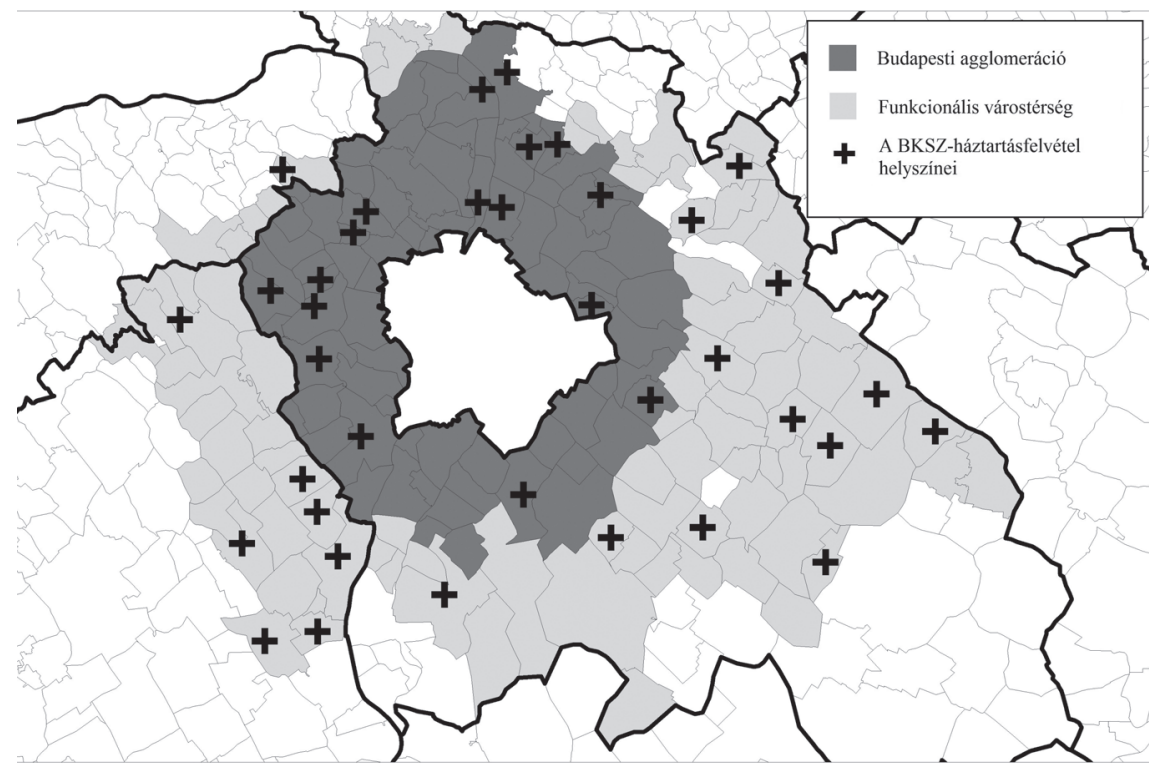

Forrás: saját szerkesztés. 
Az általános iskolások ingázásának kereteit a közoktatási törvény azon rendelkezése határozza meg, amely szerint a „szülőt megilleti a nevelési, illetőleg nevelési-oktatási intézmény szabad megválasztásának joga" (1993. évi LXXIX. törvény a közoktatásról). Bár a közoktatási törvény által megszabott iskolatípusok az alapfokú oktatásban kevésbé sokszínűek, mint a középfokú intézmények esetében, itt is lehetőség van a nem állami vagy önkormányzati (alapítványi vagy egyházi) iskolák választására, illetve hat- vagy nyolcosztályos gimnázium látogatására. Fontos megjegyezni, hogy a törvény szerint a tanuló lakhelye szerint illetékes önkormányzat köteles megtéríteni a kötelező felvételt biztosító iskolába való utazás költségeit, ha a lakóhely településén nem biztosított az oktatás.

Elfogadva a szuburbanizáció fenti értelmezését, feltevésem az, hogy a szuburbanizálódó települések sajátos ingázási viszonyokkal jellemezhetők, ami elsősorban abban nyilvánul meg, hogy a helyi általános iskola megléte ellenére magas a más településre iskolába járók aránya. A tanulmány első felében ezt a feltevést támasztom alá a budapesti funkcionális várostérségben ingázó általános iskolásokra vonatkozó települési szintű KSH-adatok vizsgálatával.

Ugyancsak a fenti szuburbanizáció-értelmezésből kiindulva feltételezem, hogy a szuburbanizálódó településeken a lakosság jövedelme, iskolai végzettsége és személygépkocsival való ellátottsága magasabb, mint az egyéb településeken. Amennyiben kimutatható, hogy e három tényező hat az iskolások ingázására is, akkor áttételesen összefüggés mutatható ki a szuburbanizáció és az általános iskolások ingázási intenzitása között. A tanulmány második részében tehát az ingázó tanulók családjának társadalmi-gazdasági helyzetére vonatkozó empirikus adatok vizsgálatával e feltevés bizonyítása a cél.

Végül pedig az általános iskolai ingázók utazási jellemzőinek (az utazás módja, távolsága és időtartama) vizsgálata alapján a tanulói ingázás következményeit mutatom be. Ez utóbbi két vizsgálati elem a 2007-ben a Budapesti Közlekedési Szövetség területén elvégzett háztartásfelvétel adatainak elemzésén alapszik.

\section{Bejárók és eljárók}

Első lépésben az ingázás intenzitását vizsgáltam meg, és feltártam a térkapcsolatok jellegzetességeit a budapesti funkcionális várostérségben. A KSH más településről bejáró általános iskolai tanulókra vonatkozó adatai alapján beazonosítottam az iskolai ingázás legfontosabb célpontjait (fogadó települések). A kibocsátó településekről viszont nem állt rendelkezésre adat, így a másik településre eljáró iskolások számára az adott településen az általános iskolás korúak (6-13 évesek) és a helyben tanulók (helyi lakosok és bejárók) számának összehasonlításával következtettem. ${ }^{2}$ 
A településekről eljáró általános iskolások számát vizsgálva a Budapestet közvetlenül övező agglomerációs zóna emelkedik ki (2. ábra). Ennek egyik oka, hogy a fiatalos korszerkezet miatt itt általában is magasabb az általános iskolás korúak aránya. Szembeötlő emellett, hogy míg a magasabb szuburbanizációs indexszel jellemezhető nyugati, északi és északkeleti területeken a Budapesttel közvetlenül határos településeken túli községek és városok is jelentősebb, 100 fö fölötti elingázással jellemezhetők, addig az FVT kevésbé szuburbanizált déli és keleti területein csak a fővárossal közvetlenül szomszédos településeken magas az elingázás. A legnagyobb kibocsátó települések tehát egybeesnek a szuburbanizáció által leginkább érintett településekkel.

A befogadó településeket vizsgálva szembeötlő Budapest túlsúlya. A fővároson belül pedig a városhatárhoz közeli területek emelkednek ki; kifejezetten jelentős az ingázás a budai kerületekbe (3. ábra). Összevetve az adatokat a legnagyobb kibocsátó településekkel, feltételezhető a nyugati agglomeráció Budához közeli települései (pl. Budaörs, Törökbálint, Biatorbágy, Budakeszi) és a budai kerületek közötti intenzívebb ingázás. Budapesten kívül jelentősebb befogadó települések még az FVT alközpontjai: Vác, Gödöllő, Szentendre, Érd, Százhalombatta és Budaörs. Közülük is elsősorban Gödöllő és Budaörs emelkedik ki 500 föt meghaladó bejáróval.

2. ábra: A településről eljáró általános iskolai tanulók száma, 2007

Outbound commuting of primary school pupils, 2007

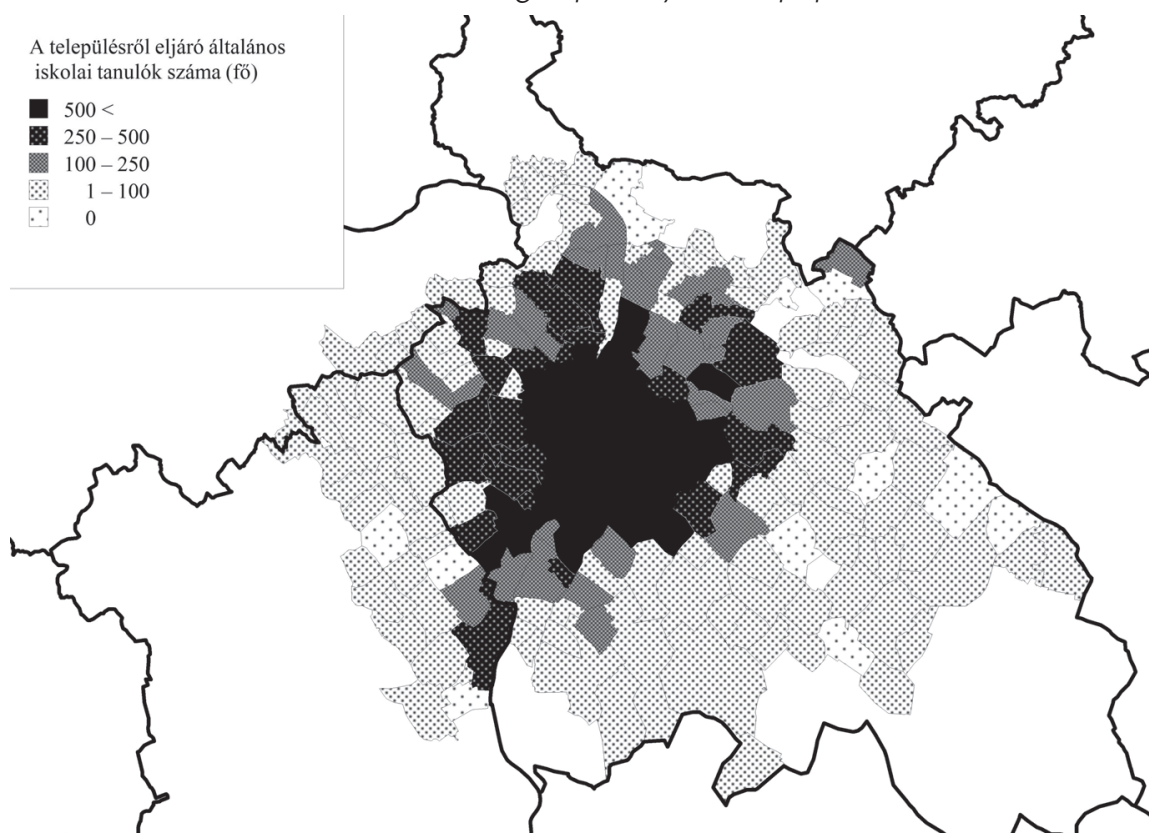

Forrás: a KSH Tájékoztatási adatbázis (2007) és saját számítások alapján saját szerkesztés. 
3. ábra: A településre bejáró általános iskolai tanulók száma, 2007 Inbound commuting of primary school pupils, 2007

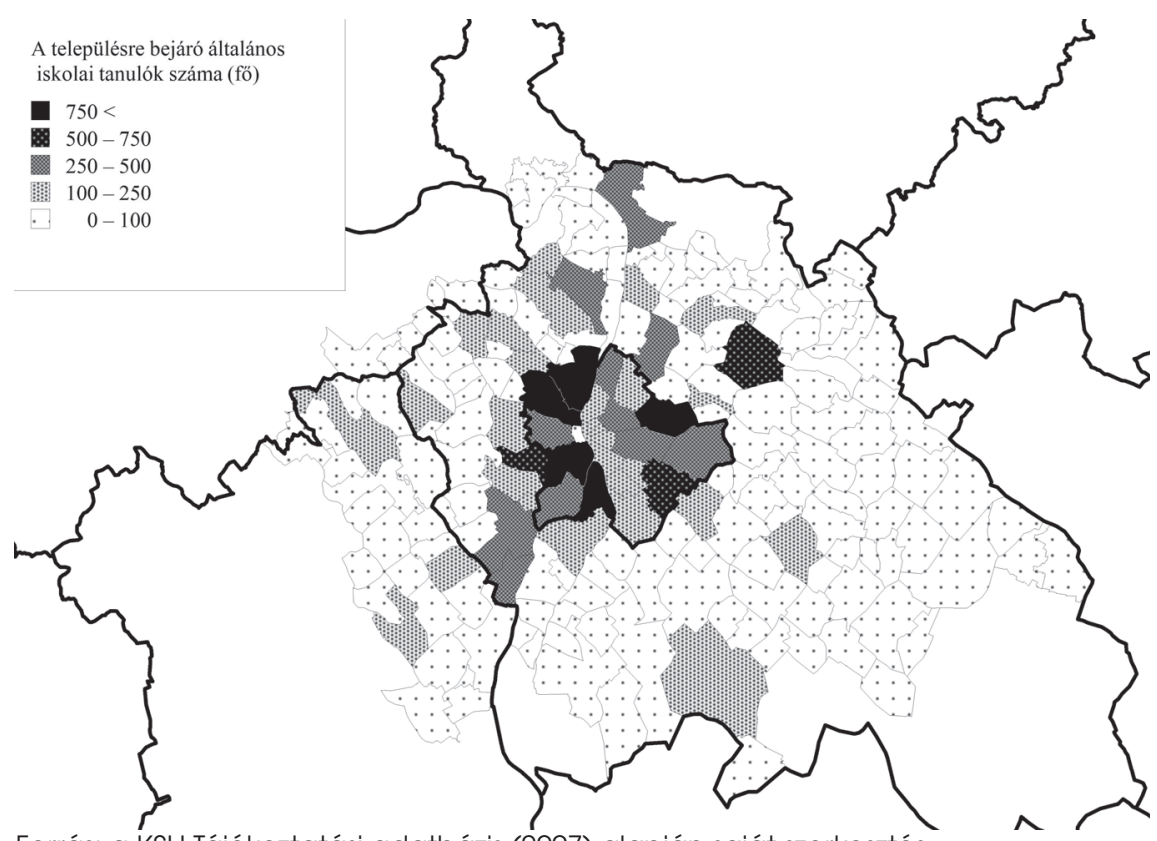

Forrás: a KSH Tájékoztatási adatbázis (2007) alapján saját szerkesztés.

Feltételezésem szerint a szuburbán térségekben a lakosság nagyobb mobilitása, a magasabb iskolai végzettségüek nagyobb aránya és a magasabb jövedelmi szint miatt intenzívebb lesz az általános iskolások ingázása. Azt fentebb láttuk, hogy az ingázó iskolások abszolút számát tekintve a hipotézis megállja a helyét, viszont a szuburbán területek eleve magasabb iskoláskorú népessége torzítja az eredményt. Célszerü ezért megvizsgálni azt is, hogy az általános iskolás korú népességből, valamint a településen tanulókból mekkora az ingázók aránya. Erre a KSH-adatok települési szinten biztosítanak lehetőséget.

Ezen a ponton célszerű az általános iskolai ingázókat két csoportra osztani. A kényszerüségból ingázók azért járnak más településre általános iskolába, mert a lakóhely településén nincs alapfokú oktatás, vagy az csak korlátozott (pl. csak alsó tagozat, összevont osztályok). (Az FVT területén csupán 7 ilyen település van.) A másik csoportba azok tartoznak, akiknél az ingázás a szülók választásának eredménye. Ők az iskolák vélt, illetve valós oktatási színvonala, az iskolába járó gyerekek társadalmi és etnikai összetétele, vagy az iskolában nyújtott speciális képzések (például Waldorf-módszer, egyházi, nemzetiségi képzés, nyelv, testnevelés, matematika, művészeti stb. tagozat), illetve szolgáltatások (például a fogyatékos tanulók kiemelt kezelése) miatt járnak másik településre. A választás alapján való ingázást azonban korlátozza, hogy noha az iskolaválasztás sza- 
bad, minden iskolának van egy beiskolázási körzete, ahonnan köteles felvenni az ott lakó gyermekeket, s más körzetekből csak a fennmaradó helyekre vehet fel tanulókat ${ }^{3}$.

A bevezetőben említett szuburbanizáció-értelmezésből kiindulva feltételezem, hogy a választás motiválta ingázás összefüggést mutat a szuburbanizáció indikátoraival.

Ahhoz, hogy célomnak megfelelően csak ez utóbbi ingázást vizsgálhassam, azt az ideális állapotot kellett feltételeznem, amelyben nincs kényszerü ingázás, mert minden településen található a helyi igényeket kielégítő általános iskola. Ehhez ki kellett szűrnöm a kényszeringázással jellemezhető településeket. Ezeket egyrészt a KSH alsó és felső tagozatos iskolások létszámát közlő adataira támaszkodva, másrészt a kistelepülések iskolai ellátottságát egyenként megvizsgálva (iskolák és önkormányzatok weboldala ${ }^{4}$ ) tettem meg $^{5}$. A további számításokat ezekkel a korrigált ingázási adatokkal végeztem.

Az általános iskolás korosztály létszámkülönbségeiből adódó torzításokat kiküszöböli, ha megvizsgáljuk, hogy az adott településen tanulók számához viszonyítva mekkora a bejárók aránya, illetve a helyben lakó általános iskolás korosztályhoz hogyan viszonyul az eljárók csoportja. Az 1. táblázat különböző területi csoportokba (a budapesti agglomeráció szektorai, az FVT agglomerációs és nem agglomerációs települései, Budapesttel határos települések) rendezve mutatja be ezeket az arányokat. Ez a csoportosítás lehetővé teszi egyrészt Budapest vonzáskörzetében az egyes területi szektorok összehasonlítását, másrészt pedig a fővároshoz való közelség hatásának értékelését.

1. táblázat: Az eljárók és bejárók aránya, valamint az átlagos szuburbanizációs index a vizsgált terület különböző szektoraiban 2007-ben

The proportion of outbound and inbound commuters and average suburbanisation index in the different sectors of the study area

\begin{tabular}{|c|c|c|c|}
\hline Terület & $\begin{array}{l}\text { A bejáró tanu- } \\
\text { lók aránya (az } \\
\text { általános } \\
\text { iskolai tanulók } \\
\text { arányában, \%) }\end{array}$ & $\begin{array}{c}\text { Az eljáró tanu- } \\
\text { lók aránya (az } \\
\text { általános } \\
\text { iskolás korúak } \\
\text { arányában, \%) }\end{array}$ & $\begin{array}{l}\text { Átlagos szubur- } \\
\text { banizációs index }\end{array}$ \\
\hline Agglomeráció északi szektor & 11,8 & 13,1 & 36 \\
\hline Agglomeráció keleti szektor & 12,2 & 26,4 & 40 \\
\hline Agglomeráció délkeleti szektor & 4,5 & 16,4 & 30 \\
\hline Agglomeráció déli szektor & 10,0 & 22,8 & 37 \\
\hline Agglomeráció nyugati szektor & 18,8 & 28,9 & 47 \\
\hline Agglomeráció északnyugati szektor & 15,9 & 33,1 & 43 \\
\hline Agglomeráció & 11,9 & 23,6 & 40 \\
\hline FVT agglomeráción kívül & 6,4 & 9,1 & - \\
\hline Budapest & 8,5 & 0,5 & - \\
\hline FVT összes (Budapest nélkül) & 10,2 & 19,3 & - \\
\hline FVT összes (Budapesttel) & 9,2 & 11,9 & - \\
\hline Budapesttel határos települések & 11,6 & 26,5 & 43 \\
\hline
\end{tabular}

Adatok forrása: saját számítások a KSH Tájékoztatási adatbázis (2007) alapján. 
Az agglomerációba tartozó településeken az eljárási arány közel két és félszerese az agglomeráción kívüli településekének. Mindeközben a bejárók aránya között csak kisebb, 5 százalékpontos különbség van. Csak a Budapesttel határos településeket vizsgálva pedig az agglomeráció átlagát is meghaladja az eljárók aránya. Ezek az adatok arra utalnak, hogy a Budapesthez közeli településekről jóval nagyobb arányban ingáznak el az általános iskolások, s valószínű, hogy a fö célpont Budapest. A fóváros jelentős vonzerejét mutatja az is, hogy Budapest esetében az eljárók aránya a bejárókhoz képest elhanyagolható.

Az agglomeráció szektorait összehasonlítva az elingázás szempontjából a nyugati és az északnyugati szektor emelkedik ki az FVT átlagát jóval meghaladó aránnyal. Ezek a szektorok egyébként az agglomeráció leginkább szuburbanizált területei, a legmagasabb szuburbanizációs indexszel. Az északi szektor esetében Vác torzítja az eredményeket, mivel saját oktatási kínálata miatt kibocsátása alacsony, valamint vonzza a környező települések lakóit is. Vác nélkül az északi szektorban is átlag fölötti, 23,7\% lenne az eljárók aránya. A nyugati szektornak nemcsak a kibocsátása, hanem a vonzása is erős, hiszen itt a legmagasabb a beingázók aránya, akik elsősorban Budakeszi, Zsámbék, Törökbálint és Budaörs általános iskoláiba járnak be. Szembetűnő a délkeleti szektor alacsony bejáróaránya, ami a vonzó iskolák hiányára utal ebben a térségben.

Összevetve az egyes szektorok szuburbanizációs indexét azok eljáróarányával, elmondható, hogy a magasabb szuburbanizációs index nagyobb elingázással párosul. A kapcsolat azonban nem lineáris, és az agglomeráció alközpontjai (Vác, Gödöllő, Szentendre) torzítják az eredményeket. A Budapesttel határos települések esetén pedig felvetődik, hogy milyen arányban határozza meg a szuburbanizáció, illetve a Budapesthez való közelség az elingázás nagyságát, illetve hogy milyen szerepe van a közlekedési kapcsolatok minőségének. E hatások elkülönítéséhez további, részletes, települési szintű vizsgálatokra lesz szükség.

Összevetve a vizsgált települések szuburbanizációs indexét és ingázási arányát, a szuburbanizációs index és az eljáró tanulók aránya között közepesen erős, 0,54-ös korrelációt, míg a bejáró tanulók arányával gyenge összefüggést $(0,27)$ találtam. Ez alapján elmondható, hogy a szuburbanizációs index és az eljáróknak a helyben lakó általános iskolás korúak számához viszonyított aránya között mérsékelten erős kapcsolat van. Ez még nem jelent ugyan ok-okozati összefüggést a szuburbanizáció és az ingázás között, de valamiféle kapcsolatra utal. A bejárókat tekintve a kapcsolat gyenge, aminek az az oka, hogy a korrelációs vizsgálatba bevont települések összesített ingázási egyenlege -9376, tehát az elingázás jóval nagyobb mértékű, mint az odaingázás. Ennek elsődleges oka Budapest vonzerejének dominanciája, hiszen a főváros önmagában 9258 bejáró általános iskolást vonz.

Az ingázási arányok alakításában a szuburbanizáció mellett nagy szerepe van az egyes iskolák vonzerejének is. Erre mutat rá Érd és Budaörs példája. Érd az FVT legnagyobb városa. A helyben lakó általános iskolás korúak eljárási aránya $24 \%$, a bejáróké pedig 8\%. Ezzel szemben a Budapesttel ugyancsak szomszédos Budaörs 
általános iskoláinak vonzereje jóval nagyobb, bár lakossága csak mintegy fele Érdének. Az általános iskolás korúaknak csak 13\%-a jár el, dacára a Budapesttel fennálló kiváló közlekedési összeköttetésnek, míg az ide bejárók aránya 23,6\%. Ennek oka valószínűleg a budaörsi iskolák jó híre és széles képzési kínálata.

Az ingázási intenzitásra és irányokra hatással lehet még a térszerkezet is. A délkeleti agglomeráció településsűrűsége jóval alacsonyabb, mint az északkeletié vagy a nyugatié, s ezért a települések közötti ingázás egyúttal nagyobb távolságot, magasabb utazási időt és költséget jelent. Ezzel szemben az intenzívebb ingázással jellemezhető területeken gyakori a települések összenövése (pl. Törökbálint-Budaörs, Pilisvörösvár-Pilisszentiván, Dunakeszi-Fót-Göd), ahol az ingázás valójában egy rövid utazást is jelenthet a szomszédos településre. Az is szembetűnő, hogy a Budapesttel határos településeken átlag feletti az általános iskolás ingázók száma. Valószínű, hogy itt a budapesti iskolák közelsége, a jó közlekedési kapcsolatok (pl. több helyen van közvetlen BKV-járat Budapestre), valamint a fővárosba ingázó szülők magasabb aránya miatt nagyobb az ingázó iskolások száma.

\section{Az általános iskolába járók családi háttere}

A KSH fent ismertetett településsoros adataiból csak az általános iskolások ingázásának volumenére és részben irányára tudtam következtetni. A diákok utazásai és a családi háttér közötti összefüggéseket a 2007-ben a Budapesti Közlekedési Szövetség (BKSZ) területén végzett reprezentatív háztartásfelvétel adatai alapján vizsgáltam. Ekkor 50 település 9000 háztartásában végeztek felmérést. A BKSZ-felmérés 50 településéből 37 esik az FVT területére (1. ábra). Jelen tanulmány elkészítéséhez a 37 településen összesen 600 nappali tagozatos általános iskolás tanuló válaszadó 3053 utazásáról rendelkezésre álló információkat használtam fel.

Korábbi kutatások (Kertesi, Kézdi 2005b, Econmet Kft. 2008) országos adatokat elemezve kapcsolatot találtak a család jövedelme, a szülők iskolai végzettsége, a család tulajdonában lévő személygépkocsik száma, valamint annak valószínűsége között, hogy a gyermek másik településre jár általános iskolába. Megvizsgáltam, hogy ezek az összefüggések az FVT vonatkozásában is fennállnak-e.

$\mathrm{Az}$ iskolaválasztási döntést jelentősen befolyásolja az ingázás költsége (Kertesi, Kézdi 2005a). Mivel az ingázás költsége a motorizált közlekedési módok (személygépkocsi, közösségi közlekedés) esetén elsősorban a megtett távolságtól függ, feltételezem, hogy a jobb anyagi helyzetben lévő családok nagyobb valószínűséggel járatják másik, távolabbi településre gyermeküket. Ezt az FVT-re vonatkozó adatok a magasabb jövedelmi kategóriák esetén megerősítették (2. táblázat). Ha magasabb a család havi nettó jövedelme, akkor a 160000 forintos határ elérése után nagyobb a család általános iskolás gyermekeinek ingázási valószínűsége is. 
2. táblázat: A helyben tanuló és eljáró általános iskolás gyermekek megoszlása a család havi nettó jövedelme szerint

Proportion of primary-school pupils commuting and attending local schools according to net family income

\begin{tabular}{ccc}
\hline A család jövedelme, Ft & Helyben tanul, \% & Eljár, \% \\
\hline$<90000$ & 83 & 17 \\
$90001-130000$ & 86 & 14 \\
$130001-160000$ & 86 & 14 \\
$160001-220000$ & 73 & 27 \\
$220000<$ & 67 & 33 \\
\hline Teljes minta & 75 & 25 \\
\hline
\end{tabular}

Forrás: saját számítások a BKSz-háztartásfelvétel alapján (2007).

Korábbi kutatások kapcsolatot találtak a szülők iskolai végzettsége és a tanulók más településre való ingázása között is. 2001-ben országos szinten az apa felsőfokú végzettsége esetén a gyermekek $42 \%$-a, az anya felsőfokú végzettsége esetén a gyermekek 37\%-a más településre járt, szemben az átlagos 23\%-kal (Kertesi, Kézdi 2005b).

Ha megvizsgáljuk a szülők iskolai végzettségét, akkor jól látszik, hogy mind az apa, mind az anya iskolai végzettsége és a gyermek iskolájának helyszíne között összefüggés van (4. ábra). A korábbi vizsgálatok eredményeit megerősítve és az FVT-re szűkítve elmondható, hogy minél magasabb a szülők iskolai végzettsége, annál jellemzőbb, hogy a gyermekük másik településre jár iskolába. Kertesi és Kézdi korábbi adataihoz képest az apa felsőfokú végzettsége esetén magasabb, $50 \%$ az eljáró gyermekek aránya. Az anya iskola végzettségét vizsgálva a korábbi, országos adatokhoz hasonló érték (38\%) adódott.

A család tulajdonában lévő személygépkocsik számát vizsgálva azt találtam, hogy az eljáró gyermekek aránya nem különbözik azon családokban, ahol 0 vagy 1 autó található (az eljárók aránya 10, illetve 11\%). Ez abból adódhat, hogy ha van a családban autó, azt az apa használja munkába járásra, míg az anya és a gyermekek csak abban az esetben tudnak ezzel a személygépkocsival utazni, ha az úti cél az apa útvonalába esik. Akkor azonban, ha a család tulajdonában két vagy több személygépkocsi van, nagyobb az ingázó tanulók aránya (19\%). Ebben az esetben az anya is mobilabb, és mivel hagyományosan az ő feladata a gyermekekről való gondoskodás és iskolába kísérés, autóval tudja szállítani a gyermeket, akár távolabbi iskolába is, különösen, ha nem dolgozik (pl. GYES-en van).

A fentieken túl azt is megvizsgáltam, hogy a szülők ingázásának ténye kapcsolatban van-e a gyermekek ingázási valószínűségével. Azt találtam, hogy nincs szignifikáns eltérés a más településre járó tanulók arányában attól függo"en, hogy valamelyik vagy mindkét szülő ingázik-e. 
4. ábra: A helyben tanuló és eljáró általános iskolás gyermekek megoszlása a szülők iskolai végzettsége szerint

Proportion of primary-school pupils commuting and attending local schools according to the parents' education level

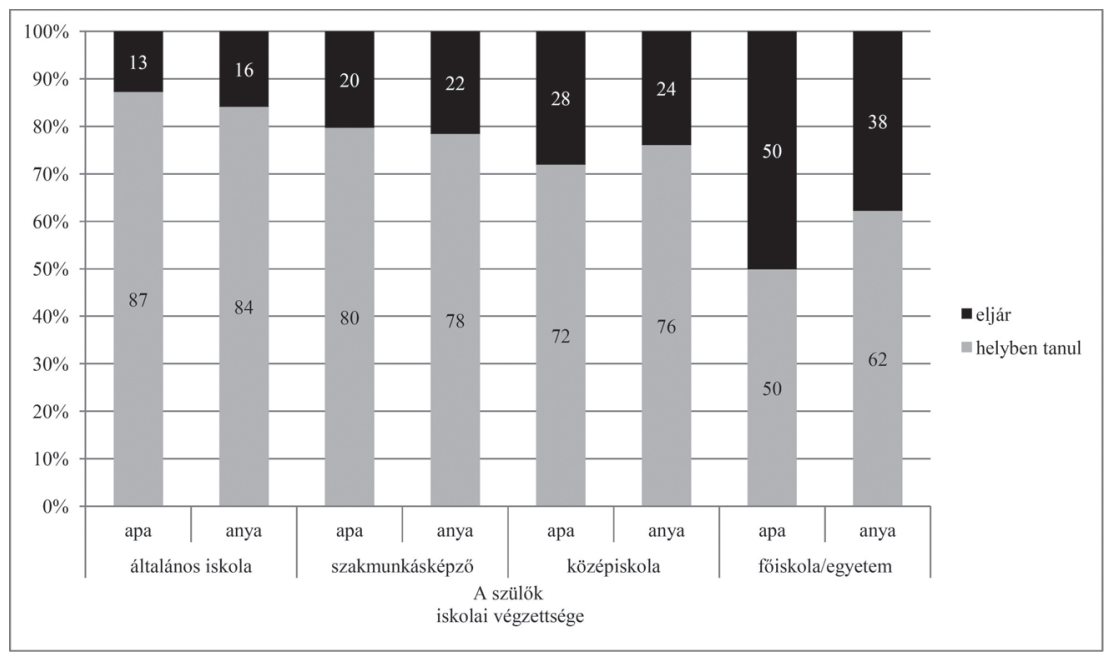

Forrás: saját számítások a BKSZ-háztartásfelvétel alapján (2007).

\section{Az ingázás következményei}

A tanulók ingázásának számos közlekedési, gazdasági, egészségügyi és társadalmi vonatkozása van. Az iskolába való ingázás hozzájárulhat a közlekedési hálózatok kapacitásproblémáihoz, amelyek akkor jelentkeznek, amikor ugyanazt a hálózati elemet, ugyanabban az időben, nagy számban kívánják igénybe venni az utazók. A kapacitásproblémák egyik oka a közlekedési módok közötti egyensúly-eltolódás. Az iskolába járás módjának változása befolyásolja a közlekedési ágak közötti munkamegosztást, s ezzel növelheti a túlzott személygépkocsihasználat által okozott torlódást és egyéb károkat (környezetszennyezés, balesetveszély stb.). Az USA-ban 1969 és 2005 között 16\%-ról 55\%-ra nőtt az iskolába személyautóval eljutó gyermekek aránya, miközben a gyaloglás és a kerékpározás aránya 42\%-ról 13\%-ra csökkent (McDonald 2005). Az Egyesült Királyságban 1990-2000 között 16\%-ról 29\%-ra nőtt a gépkocsival iskolába járók aránya, ami gyakorlatilag azt jelenti, hogy a városi utakon 8:50-kor a személygépkocsik ötöde gyermeket szállít iskolába. Mindeközben az iskolába járók átlagos utazási távolsága is nőtt, az 5-10 évesek körében 18, a 11-16 évesek körében 35\%-kal (Derek Halden Consultancy 2002). Magyarországra vonatkozó ilyen jellegü információk nem állnak rendelkezésre. 
A globális hatás mellett a forgalmi torlódások lokálisan is megjelenhetnek, különösen az óvodák és iskolák környékén, ahol azonos időpontban gyermeküket kitevő vagy felvevő szülők járművei okozhatnak torlódásokat (Wilson et al. 2007, McMillan 2007, Rhoulac 2005).

A közösségi közlekedéssel ingázó diákok számának növekedése többletkiadást jelent az államnak, hiszen a költségvetés az iskolába járáshoz használt bérlet árának 90\%-át megtéríti a szolgáltatónak. Mindeközben az iskolai oktatás az ingázás által leginkább érintett települések mindegyikén biztosított.

Az iskolába járás másik vetülete a gyermekek biztonsága. 14 éves korig a gyermekek sérülésének egyharmadát közlekedési baleset okozza, a haláleseteknek pedig ez a leggyakoribb oka. A gyermekeket legtöbbször gyalogosként és kerékpárosként éri baleset, de a szülőkkel együtt személygépkocsiban sérüléseket szerzők száma sem elhanyagolható. Baleset tulajdonképpen az iskola és a lakás távolságától függetlenül érheti a gyereket, hiszen még egy rövid szakaszon is lehetnek veszélyes kereszteződések vagy gyalogátkelőhelyek. Mégis, egy hosszabb, akár több közlekedési módot magában foglaló utazás (pl. gyaloglás és közösségi közlekedés) a balesetek bekövetkeztének valószínűségét is növeli, különösen, ha a gyermek kísérő nélkül közlekedik (Nemzeti Közlekedési Hatóság 2009).

Az iskolába járás módja közvetve hatással lehet a diákok egészségére is. Minél messzebb van ugyanis az iskola a lakóhelytől, annál valószínűbb valamilyen motorizált közlekedési mód használata (közösségi közlekedés, személygépkocsi), ami hozzájárulhat a mozgásszegény életmód kialakulásához (McMillan 2007, Cooper et. al 2003). A rendszeres testmozgás hiánya pedig betegségekhez, fáradtsághoz, stresszhez és elhízáshoz vezethet (Hillman 1997).

A fenti következmények elsősorban az utazási mód választásával, az utazási idővel és a távolsággal függenek össze. A BKSZ-felmérés adatbázisára támaszkodva ezeket a jellemzőket is megvizsgáltam.

Mivel a diákok többsége helyben jár általános iskolába, utazásainak legnagyobb részét gyalogosan (48\%) vagy kerékpárral (16\%) bonyolítja le. A közösségi közlekedés és a személygépkocsi aránya közel azonos (18, illetve 19\%). A más településre ingázó általános iskolások esetében már szinte kizárólag motorizált mód jöhet szóba: a gyermekek 64\%-a közösségi közlekedési eszközzel, 36\%-a személygépkocsi utasaként közlekedik. Ez az arány kedvező, hiszen a munkába járás célú utazásoknál éppen fordított az arány az egyéni közlekedés javára (Keserű 2010). Az adatbázis lehetőséget nyújtott arra is, hogy megvizsgáljam a gyermeküket kísérők utazási módját. Azon szülők, akik iskolába kísérik gyermeküket, jellemzően személygépkocsival teszik azt (52\%), ami rávilágít arra a korábban említett problémára, hogy az iskoláknál lokális torlódások alakulhatnak ki.

Azok a diákok, akik más településen tanulnak, jóval többet kénytelenek utazni. Az FVT-ben (Budapesten kívül) lakó általános iskolások esetében a helyi iskolában tanulóknak átlagosan 18 percet kell az iskolába járásra áldozniuk 1,1 km távolságra (egy irány), míg ingázó társaik átlagosan 36 percet utaznak, 9,6 $\mathrm{km}$ távolságra. Az ingázó általános iskolai tanulók átlagos utazási távolsága 
azonban még így is jóval alacsonyabb a középiskolások, s különösen a dolgozók utazási távolságánál. Az általános iskolások 85\%-a 10 kilométeren belüli településre ingázik, s csak elvétve akad olyan, akinél meghaladja a $20 \mathrm{~km}$-t az utazási távolság. Ez arra utal, hogy az ingázó általános iskolások többsége a szomszédos településre jár át.

A fenti adatok alapján kiszámoltam, hogy az FVT területén az állam hozzávetőlegesen havonta 100 millió forintnyi szociálpolitikai menetdíj-támogatást fizet a közlekedési szolgáltatóknak az általános iskolások kedvezményes diákbérletei után ${ }^{6}$. Az ingázó iskolások számának 10\%-os növekedése havonta mintegy 6,5 millió forinttal növeli a szükséges állami menetdíj-támogatás nagyságát.

A másik településre való ingázás egyik fontos következménye tehát a magasabb utazási idő és a távolság, s ebből következően a diákokat érő testi-lelki megterhelés növekedése, a nagyobb baleseti kockázat, illetve a magasabb utazási költség, ami egyben magasabb állami kedvezménytérítést jelent.

\section{Következtetések}

Vizsgálati területem, Budapest funkcionális várostérsége településein az ingázó diákok aránya nem magasabb, mint az országos átlag. Mivel azonban a térség településeinek majd mindegyikén van általános iskola, az ingázás motivációja alapvetően nem a helyi közoktatási intézmények hiánya, hanem a szülők választásának eredménye.

Az ingázás intenzitása az FVT-n belül eltérő. Függ egyrészt a Budapesttől való távolságtól, mivel Budapest mint egy hatalmas mágnes, az iskolák nagy minőségi és mennyiségi választékával, valamint jó közlekedési kapcsolatokkal vonzza az általános iskolásokat (illetve elsősorban szüleiket). Másrészt a főváros nyugati, északi és északkeleti vonzáskörzetében a Budapesttel nem határos településeken is jelentős ingázás tapasztalható. Ezek a területek az FVT leginkább szuburbanizált térségei, tehát kínálja magát az a feltevés, hogy a leginkább szuburbanizált településeken az általános iskolások ingázása is jellemzőbb. Ezt megerősíti az a tény, hogy a legtöbb más településről bejáró tanuló Budapest budai kerületeibe jár iskolába, amelyek a nyugati agglomerációból közelíthetők meg legkönnyebben. A szuburbanizációs index és az ingázási intenzitás kapcsolatának vizsgálata közepesen erős összefüggést mutatott a szuburbanizáció mértéke és az iskolai ingázás aránya között. Figyelembe kell azonban azt is venni, hogy a legközelebbi „kívánatos” általános iskola távolsága gyakran a térszerkezet függvénye. Hiszen azokon a területeken, ahol magas a településsűrűség (nyugati, délnyugati és északi agglomeráció), a települések összenövése miatt a szomszédos település iskolája gyakran hamarabb elérhető, mint a saját településé, tehát a szuburbanizáció nem feltétlen magyarázza önmagában az általános iskolás ingázók magasabb számát. 
Miközben a szuburbanizálódó településekről még mindig Budapest a legfőbb munkahelyi ingázási célpont, az iskolai ingázás esetén ez nem ilyen egyértelmű. Egyrészt a Budapestre való ingázás a fővárossal közvetlenül szomszédos települések kivételével aránytalanul nagy terhelést jelentene a 6-13 éves gyermekeknek, illetve költséget a családoknak; másrészt az agglomerációs településeken (pl. Budaörsön, Érden, Zsámbékon) is vannak jó hírü és népszerü általános iskolák, amelyek rövidebb utazással megközelíthetők. Ez a jelenség, vagyis az FVT-n belüli keresztirányú utazások magas száma különösen szembetűnő a Budaörsi kistérségben és a Zsámbéki-medencében, ahol mind a beingázók, mind az elingázók száma magas. Ezzel együtt a keresztingázások tekintetében is leginkább a szuburbanizálódó területek emelkednek ki. A keresztingázást azonban gyakran akadályozza a haránt irányú közösségi közlekedési kapcsolatok hiánya, ami sokszor szomszédos településeket is elválaszt egymástól.

Vizsgálataim alapján elmondható, hogy a család magasabb jövedelme, a szülők magasabb iskolai végzettsége és a család birtokában lévő 2 vagy több személygépkocsi esetén nagyobb a valószínűsége annak, hogy az általános iskolás gyermekek másik településre járjanak iskolába. Ennek alapvető indoka a mobilitásban keresendő. A másik településre való átjáráshoz egyrészt közlekedési eszközre van szükség (autó, közösségi közlekedés), másrészt költsége van, amit a szegényebb családok kevésbé engedhetnek meg maguknak. A szülők magasabb iskolai végzettsége pedig arra utalhat, hogy a főiskolát és egyetemet végzett szülők „válogatósabbak” az iskolákat illetően, s inkább figyelembe veszik a speciális képzési lehetőségeket, az iskola felszereltségét, valamint az odajárók összetételét. Ezek a jellemzők közvetve kapcsolódnak a szuburbanizálódó településekről korábban elmondottakhoz, hiszen az általam elfogadott értelmezés szerint a szuburbanizáció egyik indikátora a lakosság magasabb iskolai végzettsége, jövedelme és a nagyobb motorizációs szint. Az összefüggések feltárásakor óvatosságra int azonban az a tény, hogy ez utóbbi három indikátor összefügg egymással, hiszen általában a magasabb iskolai végzettség nagyobb jövedelmet, a magasabb jövedelem pedig személygépkocsival való magasabb ellátottságot jelent. Éppen ezért annak megállapítása, hogy a három tényező közül valójában melyik hat leginkább az általános iskolás ingázásra, részletesebb statisztikai vizsgálatokat (pl. regresszióanalízist) kíván.

A fentiek alapján valószínü, hogy a települések szuburbanizálódása az általános iskolások ingázásának növekedését vonja maga után. Ez egyrészt erősítheti a szegregációt, hiszen - amint bemutattam - a magasabb jövedelmü és végzettségű szülők hajlamosabbak másik településen iskoláztatni gyermeküket. Emiatt a helyi iskolákban a település lakosságában képviselt arányukhoz képest jóval alacsonyabb százalékban képviseltetik magukat a jobb családi háttérrel rendelkező szülők gyermekei. Emellett, az intenzívebb ingázásból következően a szuburbanizálódó területeken határozottabban jelentkezhetnek az ingázás negatív hatásai is. Az iskolások ingázása ugyanis közlekedési többletigényeket 
gerjeszt az agglomeráció települései között, miközben már ma is itt tapasztalható a legnagyobb zsúfoltság. Amennyiben a szülő személygépkocsival szállítja gyermekét, és az útvonal nem esik egybe az egyébként is munkába járásra használt útvonallal, akkor a közúti forgalom növekedése a következmény. Ha a gyermek közösségi közlekedési eszközzel utazik, egyrészt reggel és délután az autóbuszok és vonatok zsúfoltságát növeli, másrészt pedig a tanulóbérlet megvásárlásával az államnak jelentkezik többletköltsége. Ha a szülő a gyalog is könnyen elérhető általános iskola helyett a távolabbi, másik településen lévő iskolát választja, a gyermek kénytelen lesz valamilyen motorizált közlekedési módot igénybe venni, amivel elveszti annak lehetőségét, hogy a gyaloglás vagy kerékpározás egészségügyi előnyeiből részesüljön.

Összefoglalásul, eredményeim azt mutatják, hogy a szuburbanizálódó területeken a jobb közlekedési kapcsolatok, az iskolák nagyobb választéka, a lakosság jobb jövedelmi helyzete, magasabb iskolai végzettsége és ebből következően nagyobb mobilitása, illetve személygépkocsival való jobb ellátottsága miatt az általános iskolások ingázása intenzívebb, mint más területeken, ha csak a szülők döntése alapján létrejövő ingázást vesszük figyelembe.

Tekintve az ingázás fent ismertetett környezeti, egészségügyi és közlekedési következményeit, valamint a közösségi közlekedésben a tanulóbérletek és jegyek kapcsán az állam részéről felmerülő jelentős finanszírozási igényt, el kellene gondolkodni azon, hogy nem lenne-e célszerübb az elővárosi övezet iskoláiban az oktatási-nevelési színvonal emelésének támogatása, annak érdekében, hogy minél több gyermek helyben járjon iskolába.

Ez a vizsgálat az iskolások ingázásának csak néhány aspektusát tudta felvillantani. A lakóhelytől eltérő településen való iskoláztatás pontos motivációit egy célzott felméréssel lehetne kideríteni, a nagyobb léptékủ folyamatokról pedig a 2011-es népszámlálás adatainak publikálása után lehet aktuális képet festeni.

\section{Jegyzetek}

1 A szuburbanizációs index számítása: a lakónépesség változása 1995-2005, ezrelékben; vándorlási egyenleg, 1995-2005, ezrelékben; a lakásállomány változása 1995-2005, százalékban; az ezer före jutó személygépkocsik száma, 2005; az egy főre jutó adóköteles jövedelem, 2002; diplomások aránya a 25 éves vagy idősebb népességből, 2001 értékein egységnormálást hajtottam végre (a legjobb értékkel rendelkező település 1-es, a legrosszabb 0-s értéket kapott, a többi település eloszlása pedig megfelelt eredeti eloszlásának), majd a kapott hat adatsor adatai számtani átlagának százszorosaként jött létre a szuburbanizációs index. Az index csak a Pest megyében található településekre állt rendelkezésre, így az itt közölt eredmények is csak erre a területre vonatkoznak (Bajmócy 2003 és Keserü 2003 alapján).

2 E számítási mód esetén az adatokat némileg torzíthatja, hogy a hatéves korosztályban a születési dátumtól, a gyermek fejlettségétől és a szülő döntésétől függően nem minden gyermek kezdi meg az általános iskolát. Hasonló okok, valamint az esetleges osztályismétlések vagy egészségügyi indokok miatt a 14 éves korosztályban is találhatók még olyanok, akik az általános iskola valamelyik utolsó évfolyamába járnak. A 6 és a 14 éves korosztály torzulásai azonban - vélemé- 
nyem szerint - kiegyenlítik egymást, amit az is igazol, hogy országos viszonylatban a 6-13 éves korosztály létszáma és az általános iskolások létszáma között csupán 1\%-os eltérés van.

3 Erre jó példa a leányfalui általános iskola, ahol 1990 és 1997 között folyamatosan csökkent a tanulói létszám, mivel a helyszűke miatt a párhuzamos osztályokat megszüntették. Ez azt jelentette, hogy a körzeten kívül, tehát a más településen élőket nem vették fel. Az iskola felújítása és bővítése után azonban a tanulói létszám ismét emelkedni kezdett. Jelenleg a tanulók 30\%-a más településről jár be, noha Pócsmegyer kivételével az összes környező településen van általános iskola (Móricz Zsigmond Általános Iskola és Napköziotthonos Óvoda, 2011).

4 A weboldalak információra azért volt szükség, mert a vizsgált évre (2007) nem állt rendelkezésre adat arról, hogy mely településeken volt korlátozott az alapfokú oktatás (csak 1-4. vagy 1-6. osztályok). Az így szerzett adatok többségéből egyértelműen kiderült, hogy a vizsgált évben volt-e mind a nyolc osztályban oktatás, néhány esetben azonban erre csak a jelenlegi helyzetre vonatkozó adatokból következtethettem.

5 Kényszeringázó-településnek jelöltem minden olyan települést, ahol nincs általános iskola, vagy annak csak bizonyos évfolyamai működnek. A kényszeringázó-települések eljáró iskolásai a körzeti iskolák települése esetében mint bejárók jelennek meg, így ezeket az adatokat is korrigálni kellett. A KSH-adatokból számított ingázási adatokat a következőképpen módosítottam a kényszeringázó- és a kényszeringázókat befogadó települések esetében: ha az adott településen nem működik általános iskola, a településről eljáró iskolások számának 21\%-át tekintettem valójában eljárónak (mivel a vizsgált területen, Budapestet nem tekintve, átlagosan az általános iskolás korúak 21\%-a tanult más településen); amennyiben nem csak négy vagy hat osztállyal müködik az iskola a településen, akkor a helyben tanulók számát a megfelelő arányban kiegészítettem (pl. 20 alsó tagozatos esetén 20 felső tagozatossal); azokon a településeken, ahol körzeti iskola működik, tehát ahová az iskolával vagy felső tagozattal nem rendelkező településekről bejárnak az iskolások, a bejárók számát annyival csökkentettem, mint amennyivel az előző két lépésben a küldő településeken az eljárók számát.

6 A számítás abból indult ki, hogy az FVT területén ingázó diákok 64\%-a közösségi közlekedéssel utazik, átlagosan $10 \mathrm{~km}$ távolságra. A számítás alapja a menetrend szerinti autóbuszokra váltható 10 km-es diákbérlet 2012-ben érvényes ára volt, ami 90\%-os kedvezményt tartalmaz a teljes árú bérlethez képest. Hangsúlyozom, hogy ez az adat csak nagyságrendet jelöl.

\section{Irodalom}

Antikainen, J. (2005): The Concept of Functional Urban Area. Findings of the ESPON project 1.1.1. Informationen zur Raumentwicklung, 7., 447-452.

Bajerski, A. (2010): How suburbanisation affects the functioning and governing of education at the local level - the evidence from the Poznań metropolitan region (Poland). In: Šumberová M. (szerk.): Geografie pro život ve 21. století. Ostravská univerzita v Ostravě, Ostrava, 459-446.

Bajmócy P. (2003): Vidéki szuburbanizáció Magyarországon. PhD-disszertáció (kézirat), Szegedi Tudományegyetem, Szeged

Beluszky P. (1999): A budapesti agglomeráció kialakulása. In: Társadalmi-gazdasági átalakulás a budapesti agglomerációban I., Regionális Kutatási Alapítvány, Budapest, 27-68.

Cooper, A. R. et al. (2003): Commuting to school: Are children who walk more physically active? In: American Journal of Preventive Medicine, 4., 273-276.

Derek Halden Consultancy (2002): Review of Research on School Travel. Scottish Executive Central Research Unit, Glasgow. http://www.scotland.gov.uk/Publications/2002/05/14690/4172 Letöltés: 2011. szeptember 12.

Dövényi Z., Kovács Z. (1999): A szuburbanizáció térbeni-társadalmi jellemzői Budapest környékén. Földrajzi Értesito", 1-2., 33-58. 
Econmet Kft. (2008): Empirikus elemzés a szabad iskolaválasztás révén bekövetkező általános iskolai körzetszintű és településközi mobilitásról

http://www.oktatasikerekasztal.hu/hattertanulmanyok/10/econmet_empirikus.pdf Letöltés: 2011. január 22.

Hardi T. (2002): Szuburbanizációs jelenségek Győr környékén. Tér és Társadalom, 3., 57-83.

Hillman, M. (1997): The potential of non-motorised transport for promoting health. In: Tolley, R. (ed.): The Greening of Urban Transport: Planning for Walking and Cycling in Western Cities. John Wiley \& Sons Ltd., London, 21-26.

Izsák É. (1999): A települési sorrend megváltozása a szuburbanizációs index alapján a budapesti agglomerációban. Földrajzi Értesíto", 1-2., 83-92.

Kertesi G., Kézdi G. (2005a): Általános iskolai szegregáció I. rész. Közgazdasági Szemle, április, 317-355.

Kertesi G., Kézdi G. (2005b): Általános iskolai szegregáció II. rész. Közgazdasági Szemle, május, 462-479.

Keserű I. (2004): A szuburbanizáció közlekedési vonatkozásai a Budapest környéki szuburbanizálódó települések példáján. In: Kovács F. (szerk): II. Magyar Földrajzi Konferencia, Szeged, 2004. Szegedi Tudományegyetem, Szeged http://geography.hu/mfk2004/mfk2004/cikkek/keseru_imre.pdf

Keserü, I. (2010): Cross- and reverse commuting: are mobility patterns changing in the suburban areas of Central and Eastern Europe? In: AET (ed.): Proceedings of the European Transport Conference 2010, Association for European Transport (AET), Glasgow http://etcproceedings.org/paper/download/4558 Letöltés: 2012. március 5.

Kiss J. (1999): A város-vidék peremzóna személyközlekedésének átalakulási folyamatai az Alföld négy megyeszékhelyén (1980-1998). Alföldi Tanulmányok, 17.112-130.

Kovács K. (1999): A szuburbanizációs folyamatok a fovárosban és a budapesti agglomerációban. In: Barta Gy., Beluszky P. (szerk.): Társadalmi-gazdasági átalakulás a budapesti agglomerációban I., Regionális Kutatási Alapítvány, Budapest, 91-114.

McDonald, N. C. (2005): Children's Travel: Patterns and Influences. PhD-disszertáció. Kézirat. http://uctc.net/research/diss118.pdf Letöltés: Letöltés: 2011. január 22.

McMillan, T. E. (2007): The relative influence of urban form on a child's travel mode to school. In: Transportation Research Part A: Policy and Practice 1., 69-79.

Móricz Zsigmond Általános Iskola és Napköziotthonos Óvoda (2011): Bemutatkozás. http://www.leanyfalu.hu/iskola/index.php?lang=1\&modules=fck\&menu=69 Letöltés: 2012. február 6.

Nemzeti Közlekedési Hatóság (2009): Felmérés az általános iskolások közlekedésbiztonsági tudásáról. http://www.scribd.com/doc/56005739/1/A-TEMA-AKTUALITASA Letöltés: 2012. március 6.

Rhoulac, T. D. (2005): Bus or Car?: The Classic Choice in School Transportation, Transportation Research Record, 1922, Issue 1, January, 2005, 98-104.

Szirmai V. (2011): A nagyváros szélén: A városi terjeszkedés térbeli társadalmi problémái. Tér és Társadalom, 1., 20-41.

Timár J. (1994): A szuburbanizáció néhány elméleti kérdése és alföldi vonásai - Kandidátusi értekezés (kézirat), Békéscsaba

Timár J., Baukó T. (1999): A „város-vidék peremzóna” néhány sajátossága és szerepe az alföldi városok átalakulásában. Alföldi Tanulmányok, 17, 94-110.

Timár J. (1999): Elméleti kérdések a szuburbanizációról. Földrajzi Értesitő, 1-2., 7-31.

UNIVERSITAS-Arrabona Kft. (2010): Oktatási intézmények közlekedésfejlesztési tanulmányterve a TravelPlanplus projekt keretében.

http://www.travelplanplus.eu/downloads/portfolios/gyor/MC_Travel_Plan_tanulmany.pdf Letöltés: 2011. december 12.

Wilson, E. J. et al. (2007): The implications of school choice on travel behavior and environmental emissions. Transportation Research Part D: Transport and Environment, 7., 506-518.

1993. évi LXXIX. törvény a közoktatásról (2012).

http://net.jogtar.hu/jr/gen/hjegy_doc.cgi?docid=99300079.TV Letöltés: 2012. június 30. 


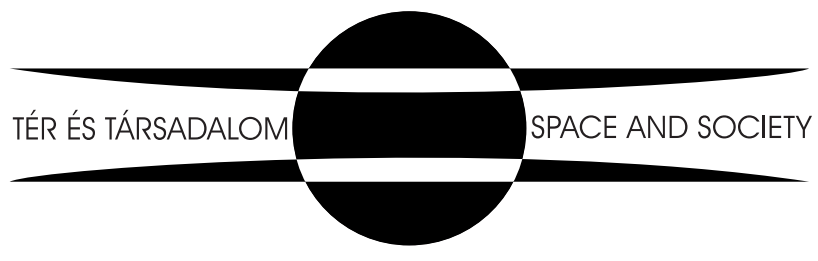

